\title{
Psychological Career Resources and Work Engagement of Early Career Consulting Staff
}

\author{
Jenny Venter \\ University of Pretoria \\ Melinde Coetzee \\ University of South Africa
}

Johan S. Basson

University of Pretoria

Address correspondence to Professor Melinde Coetzee, Department of Industrial and Organisational Psychology, P.O. Box 392, University of South Africa, 0003, Pretoria, South Africa. E-mail: coetzm1@unisa.ac.za

This study explored whether employees' psychological career resources significantly predicted their work engagement. A non-probability sample of 111 early career (26-40 years of age) white male and female staff in a South African human resource software and technology consulting services company participated in the study. Data were collected using the Psychological Career Resources Inventory and the Utrecht Work Engagement Scale. A cross-sectional survey design and quantitative statistical procedures were used to analyse the data. Stepwise regression analyses indicated that behavioural adaptability significantly and positively predicted vigour, dedication and absorption. Self-esteem positively predicted vigour and dedication whilst career purpose negatively predicted vigour. Career venturing and self/other skills negatively predicted dedication. It was concluded that psychological career resources contributed to explaining variances in work behaviour.

Keywords: psychological career resources, work engagement, career development, self-esteem, behavioural adaptability

Achieving career success involves a sense of personal agency or exerting active control over one's behaviour and environment (Converse et al., 2012; Savickas \& Porfeli, 2012). Personal agency is premised on the motivation to pursue a desired career in a work environment (Converse et al., 2012; Salmelo-Aro et al., 2012; Verbruggen, 2012). Pro-active work orientations and behaviour are aspects of individuals' employability and job performance (Alessandri, Vecchione, Tisak, Deiana, Caria, \& Caprara, 2012; Weigl, Hornung, Parker, Petru, Glaser, \& Angerer, 2010).

The development of personal agency and work engagement depends on job and personal resources (Converse et al., 2012; Weigl et al., 2010). Resources relate to the environmenta and individual factors that support the working person in successfully coping with job demands, attaining goals, and achieving personal growth and development (Demerouti, Bakker, Nachreiner, \& Schaufeli, 2001; Weigl et al., 2010). The present study examined the role of individuals' psychological career resources in predicting their work engagement. This is an important study goal in that psychological career resources are related to organisational commitment and job embeddedness (Ferreira \& Coetzee, 2010), and work engagement (Tladinyane, 2013).

\section{Psychological Career Resources and Enablers}

Psychological career resources are work meta-capacities that enable individuals to adapt to changing work environments (Coetzee, 2008, 2013). Coetzee (2013) posits that individuals need capacities in five key domains of psychological career re- sources in order to proactively engage in agentic work/career behaviour: (1) clear career preferences and (2) career values; (3) skills that enable effective and proactive career planning/self-design, reinvention and development (career enablers); (4) intrinsic career motivations that drive individuals' career actions and intentionalities (career drivers); and (5) psycho-social career meta-capacities that facilitate resiliency and adaptability within individuals' unique social-cultural contexts (career harmonisers). As shown in figure 1, Coetzee (2008; 2013) differentiates between four types of career preferences:

Stability/expertise: This refers to a preference for a career that provides security, stability and opportunity for development in a specialist field.

Managerial: This refers to a preference for vertical mobility with more responsibility, decision-making power and influence as career success.

Creativity/variety: This refers to the preference for a wide variety of tasks that require the application of a variety of competencies (skills and knowledge) in original or novel ways.

Autonomy/independence: This refers to the preference for a work environment that allows freedom from disturbance from external sources and authority and influence in decision-making.

The career preferences are supported by two core career values (see Figure 1). The growth/development career value refers to the importance that the individual places on personal and professional opportunities to grow and develop. The authority/influence career value refers to the importance that the individual places on the responsibility for others, having authority 
over others and having influence on important organisational events or projects (Coetzee, 2008). The career preferences are the activities (career action) undertaken by people to implement the career self-concept and express preferred career values in order to satisfy the needs underpinning their career preferences (Coetzee, 2013; Super, 1995). Individuals with well-differentiated career preferences and values tend to have higher levels of subjective career well-being (Coetzee \& Schreuder, 2012); career adaptability and job embeddedness (Ferreira, 2012) and devote more resources (time, energy, attention) to their jobs, occupations and careers (Tladinyane, 2013), thereby increasing their chances of objective career success (Coetzee, 2013). Tladinyane (2013) found that the variety/creativity career preference and growth/development career value relate strongly to people's commitment to their careers and their sense of vigour and absorption in their work.

Career enablers relate to transferable practical and creative skills, and self-management and interpersonal skills that help people succeed in their careers (Coetzee, 2008; Ferreira, Basson, \& Coetzee, 2010).
Career drivers motivate individuals to achieve intrinsic goals. Internalised goals are appraised in terms of autonomous motivation (Sheldon, 2002). Autonomous motivation has been linked to higher levels of sustained effort in achieving goals and higher levels of effectiveness in the effort (Sheldon, 2002). Career drivers speak to an individual's sense of purpose, career directedness and willingness to explore career possibilities (Coetzee, 2013). Individuals with a strong sense of career purpose show higher levels of job satisfaction as well as life satisfaction and are absent from work less. They also experience a sense that their work contributes in some way to the greater community. Career directedness refers to how clearly an individual sees his or her career goals, but also refers to how clear an individual is on locating resources that will assist him or her to attain career goals or career opportunities (Coetzee, 2008; 2013). Career venturing refers to how comfortable individuals are with taking risks in order to find and explore career opportunities. Whilst the career enablers help individuals to open up to new potentialities and make sense of their lives, the career drivers constitute the motivation and drive to give their life identity, to help express, create or define who they are in the career con-

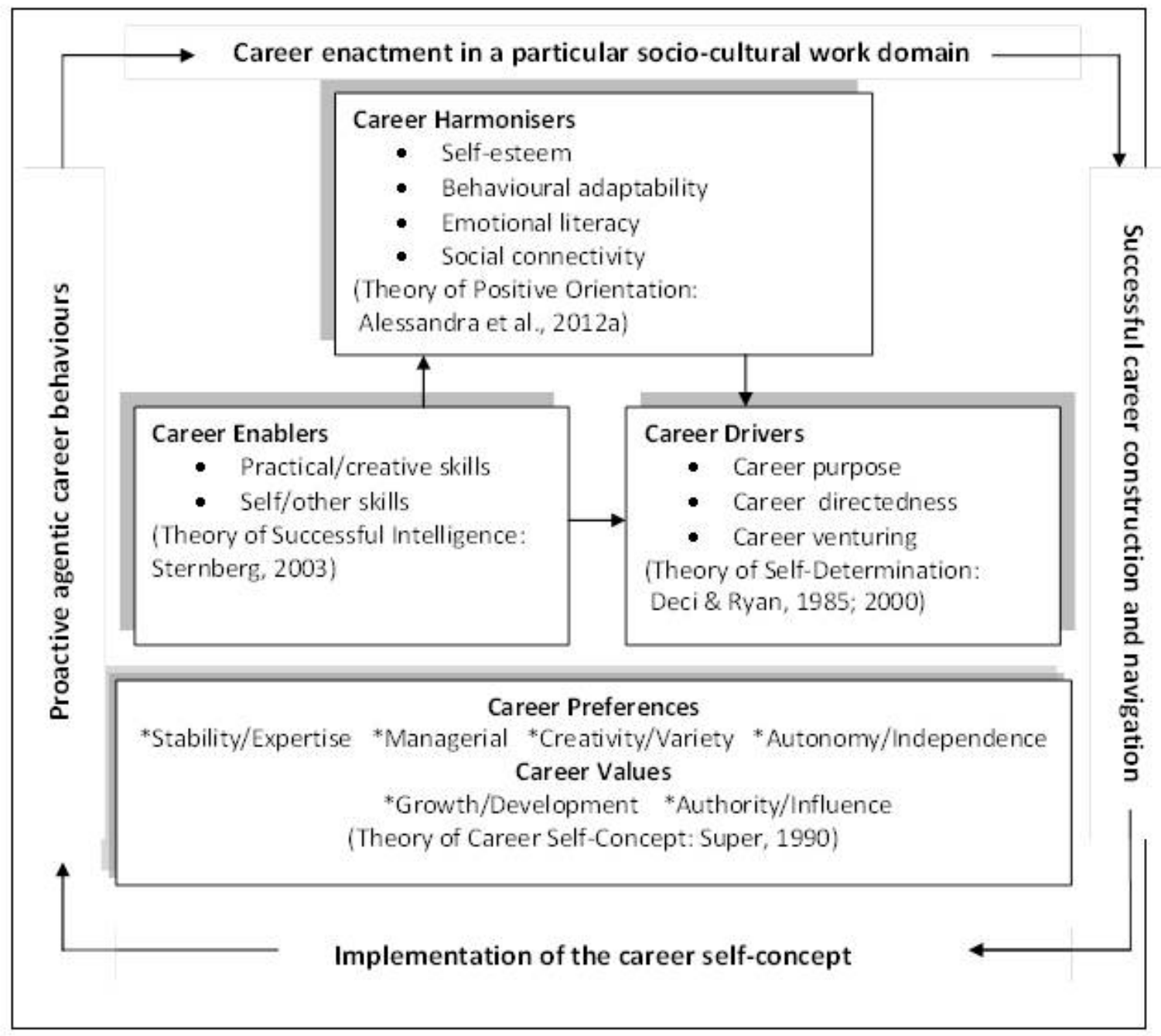

Figure 1. The psychological career resources framework (based on Coetzee, 2013). 
struction process (Coetzee, 2013). Tladinyane (2013) found a positive link between individuals' career directedness and career venturing and their commitment to their careers and their sense of vigour and absorption in their work.

Career harmonisers (individuals' self-esteem, behavioural adaptability, emotional literacy and social connectivity) are psychological resources that help to rein in the career drivers whilst also providing the psychological flexibility and resilience individuals need so that they do not burn themselves out in the process of reinventing and navigating the career (Coetzee, 2013).

Career harmonisers are significant predictors of individuals' life satisfaction, job and career satisfaction, sense of happiness and perceiving their work as meaningful. Ferreira (2012) found the career harmonisers to be positively related to individuals job embedded-fit and -links (sense of belonging) in the organisation. Tladinyane (2013) found that a high level of self-esteem increases individuals' commitment to their careers and their sense of vigour and absorption in their work.

\section{Work Engagement}

Work engagement is an active, fulfilling and positive work-related state that is characterised by feelings of vigour (emotional energy, physical strength, cognitive liveliness, resilience, and a commitment to work hard), dedication (involvement, enthusiasm, pride, and challenge) and absorption (concentration on and well-being during work (Schaufeli, Bakker \& Salanova, 2006; Vecina et al., 2012). High levels of work engagement lead to an increase in job resources over time (Schaufeli, Bakker \& Van Rhenen, 2009). Vecina et al. (2012) point out that work engagement has been linked to job satisfaction, organisational commitment, personal initiative, prosocial behaviour, motivation to learn and life satisfaction. These constructs have all been related to positive work orientations, attitudes and behaviours that lead to an increase in job performance (Mendes \& Stander, 2011; Mirheidary, Siadat, Hoveida, \& Abedi, 2012; Vecina et al., 2012).

Work engagement appears to be a relatively stable phenomenon in the continued presence of specific job and organisational characteristics (Macey \& Schneider, 2008) and certain psychological conditions (Khan, 1990). Khan (1990) posits that work engagement harnesses organisation members' selves to their work roles. Engaged employees express themselves on a physical, cognitive and emotional level in the role they are performing, and when they are not engaged they will protect themselves by withdrawing or defending themselves on these same three levels. According to Khan's (1990) theory of psychological conditions, engagement is dependent on the psychological conditions of psychological meaningfulness, psychological safety and psychological availability. May, Gilson, and Harter (2004) found positive links between these three psychological conditions and engagement, the strongest link being with psychological meaningfulness. Furthermore, job enrichment and role fit were found to influence psychological meaningfulness. Fulfilling co-worker relationships and supportive managerial relationships were found to correlate positively with psychological safety, while group norms and self-consciousness correlated negatively with psychological safety. Managerial relationships had the greatest impact on psychological safety.

Work engagement appears further to be dependent on job and personal resources (Bakker, Schaufeli, Leiter, \& Taris, 2008). Job resources represent characteristics of the job that are functional in obtaining career-related objectives, encourage personal development and lessen job demands (Demerouti et al., 2001; Tremblay \& Messervay, 2011). Personal resources are associated with resiliency and positive self-evaluations (for example, self-esteem, self-efficacy, and optimism) that enable individuals to control and influence their environment (Hobfoll, Johnson, Ennis, \& Jackson, 2003; Tremblay \& Messervay, 2011). Conservation of resources theory (Hobfoll, 2001;2002) postulates that the presence of key resources facilitates the development and use of other resources. Researchers have also observed a reciprocal relationship between job and personal resources and work engagement (Weigl et al. 2010).

\section{Goals of the Study}

The present study investigated whether individuals' psychological career resources significantly and positively predict their work engagement. Research suggests that work engagement results from a motivational process triggered by job resources (e.g. perceived job control, support, and feedback). Work engagement also seems to be affected by personal resources (individual characteristics) such as self-efficacy, organisational-based self-esteem, and optimism (Weigl et al., 2010; Xanthopoulou, Bakker, Demerouti, \& Schaufeli, 2007). However, limited research (Tladinyane, 2013) is available on the relationship between individuals' psychological career resources and their work engagement. The present study therefore aimed to answer the following research questions:

- How do the psychological career resources of employees relate to their work engagement?

- Do employees' career preferences, career values, career drivers, career enablers, and career harmonisers significantly and positively predict their vigour, dedication to, and absorption in their work?

\section{Method}

\section{Participants}

The participants comprised a non-probability sample of 111 white early career (25-40 years: $90 \%)$ consultants at a medium-sized South African firm, specialising in payroll and human resource software and technology solutions services. Males represented $27 \%$ and females $73 \%$ of the sample. The participants had a post-matric level qualification and an average of three years of work experience.

\section{Measuring Instruments}

Participants completed the Psychological Career Resources Inventory (PCRl; Coetzee, 2008) and the Utrecht Work Engagement Scale (UWES-9; Schaufeli et al., 2006). They also provided data on their demographics.

The PCRI is a 64 item measure of five subscales (career preferences, career values, career enablers, career drivers and career harmonisers). Items are scored on a 6 point Likert scale ( 1 = Never, 6 = Always). Coetzee (2008), Coetzee and Bergh (2009) and Ferreira (2010; 2012) reported internal consistency reliabilities ranging between .70 and .90 for the PCRI in the South African context. In terms of the present study, Cronbach's alpha coefficients for each subscale ranged between .65 and .87.

The UWES-9 is a 9-item self-report measure of work engagement in three subscales (vigour - 3 items, dedication - 3 items, and absorption - 3 items). The UWES-9 is scored on a seven-point Likert-type scale ( $0=$ Never, $6=$ Everyday). Coetzer and Rothmann (2007) reported internal consistency reliabilities ranging between .73 and .91 for the UWES in the South African 
context. The following internal consistency reliabilities wee obtained for the sample of the present study: vigour (.82), dedication (.89) and absorption (.76).

\section{Procedure}

Ethical clearance and permission to conduct the survey were obtained from the participating organisation. Participation was voluntary and the respondents gave their permission for the results to be used for research purposes only. The anonymity and confidentiality of all the participants were ensured. A sample of 111 usable questionnaires was returned from a total population of 557 employees, yielding a response rate of $20 \%$.

\section{Data Analysis}

The SAS system was used to analyse the data. The Pearson product moment correlation was used to determine the strength and direction of the relationship between the PCRI and UWES variables. Stepwise multiple regression analyses were conducted to predict work engagement from psychological resources. $R^{2}$ was used to interpret the practical significance of the results. In order to counter the probability of a Type I error, it was decided to set the significance value for interpreting the results at a $95 \%$ confidence interval level $(p \leq .05)$.

\section{Results}

\section{Descriptive Statistics}

Tables 1 and 2 present the descriptive statistics for the study data important for clarifying the relationships for prediction.

The collinearity diagnostics showed that, in line with the guidelines of Field (2009) for concerns about multi-collinearity, the zero-order correlations (shown in Table 2) were well below the level of concern $(r \leq .80)$, that the variance inflation factors did not exceed 10, that the condition index was well below 15 , and that the tolerance values were close to 1.0 (Field, 2009). The beta weights could therefore be interpreted with greater confidence.

Three models were tested to predict work engagement from psychological resources as described below.

\section{Psychological Career Resources as Predictors of Work Vigour}

Model 1, shown in Table 3, assessed which of the psychological resources contributed the most in explaining the variance in the UWES vigour variable. Model 1 explained $34 \%\left(R^{2}=\right.$ $.34 ; p \leq .05$; large practical effect) of the variance in vigour. The career harmoniser variables self-esteem $(\beta=.54 ; p \leq .001)$, behavioural adaptability $(\beta=.54 ; p \leq .01)$ and career purpose $(\beta=$ $-.34 ; p \leq .01)$, contributed the most in explaining the variance in vigour.

\section{Psychological Career Resources as Predictors of Work Dedication and Absorption}

Model 2 assessed which of the PCRI variables contributed the most in explaining the variance in the UWES dedication variable. Model 2 explained $30 \%\left(R^{2}=.30 ; \mathrm{p} \leq .05\right.$; large practical effect) of the variance in dedication. Similar to model 1, the career harmoniser variables self-esteem $(\beta=.57 ; p \leq .001)$ and behavioural adaptability $(\beta=.69 ; p \leq .001)$ contributed the most in explaining the variance in dedication. Career venturing $(\beta=$ $-.28 ; p \leq .01)$ and self/other skills $(\beta=-.41 ; p \leq .05)$ negatively and significantly contributed in explaining the variance in dedi-

Table 1

Descriptive Statistics: Means, Standard Deviations, and Internal Consistency Reliabilities

\begin{tabular}{|c|c|c|c|}
\hline Variables & Mean & Standard Deviation & Cronbach's alpha \\
\hline \multicolumn{4}{|l|}{ Career preferences (PCRI) } \\
\hline Stability/expertise & 5.12 & .66 & .70 \\
\hline Managerial & 4.08 & 1.13 & .86 \\
\hline Variety/creativity & 4.50 & 1.03 & .87 \\
\hline Independence/Autonomy & 4.30 & .84 & .65 \\
\hline \multicolumn{4}{|l|}{ Career values (PCRI) } \\
\hline Growth/development & 5.28 & .71 & .77 \\
\hline Authority/influence & 4.28 & 1.04 & .81 \\
\hline \multicolumn{4}{|l|}{ Career enablers (PCRI) } \\
\hline Practical/creative skills & 4.61 & .87 & .81 \\
\hline Self/other skills & 5.07 & .63 & .77 \\
\hline \multicolumn{4}{|l|}{ Career drivers (PCRI) } \\
\hline Career purpose & 5.00 & .83 & .80 \\
\hline Career directedness & 4.47 & .90 & .80 \\
\hline Career venturing & 4.16 & 1.15 & .87 \\
\hline \multicolumn{4}{|l|}{ Career harmonisers (PCRI) } \\
\hline Self-esteem & 4.65 & .83 & .83 \\
\hline Behavioural adaptability & 4.84 & .69 & .82 \\
\hline Emotional literacy & 4.66 & .93 & .85 \\
\hline Social connectivity & 4.85 & .77 & .87 \\
\hline Vigour (UWES) & 4.21 & 1.08 & .82 \\
\hline Dedication (UWES) & 4.60 & 1.20 & .89 \\
\hline Absorption (UWES) & 4.50 & 1.06 & .76 \\
\hline
\end{tabular}


Table 2

Pearson Product-Moment Correlations

\begin{tabular}{|c|c|c|c|}
\hline Variables & Vigour & Dedication & Absorption \\
\hline \multicolumn{4}{|l|}{ Career preferences } \\
\hline Stability/expertise & $\mathrm{n} / \mathrm{s}$ & $\mathrm{n} / \mathrm{s}$ & $n / s$ \\
\hline Managerial & $.20^{\star}$ & $\mathrm{n} / \mathrm{s}$ & $\mathrm{n} / \mathrm{s}$ \\
\hline Variety/creativity & $.26^{\star \star}$ & $\mathrm{n} / \mathrm{s}$ & $.24^{\star \star}$ \\
\hline Independence/Autonomy & $\mathrm{n} / \mathrm{s}$ & $\mathrm{n} / \mathrm{s}$ & $\mathrm{n} / \mathrm{s}$ \\
\hline \multicolumn{4}{|l|}{ Career values } \\
\hline Growth/development & $\mathrm{n} / \mathrm{s}$ & $\mathrm{n} / \mathrm{s}$ & $.20^{*}$ \\
\hline Authority/influence & $.22^{*}$ & $n / s$ & $n / s$ \\
\hline \multicolumn{4}{|l|}{ Career enablers } \\
\hline Practical/creative skills & $\mathrm{n} / \mathrm{s}$ & $\mathrm{n} / \mathrm{s}$ & $n / s$ \\
\hline Self/other skills & $.18^{\star}$ & $n / s$ & $n / s$ \\
\hline \multicolumn{4}{|l|}{ Career drivers } \\
\hline Career purpose & $\mathrm{n} / \mathrm{s}$ & $\mathrm{n} / \mathrm{s}$ & $n / s$ \\
\hline Career directedness & $.31^{\star *}$ & $.29^{\star \star}$ & $.24^{\star \star}$ \\
\hline Career venturing & $\mathrm{n} / \mathrm{s}$ & $\mathrm{n} / \mathrm{s}$ & $\mathrm{n} / \mathrm{s}$ \\
\hline \multicolumn{4}{|l|}{ Career harmonisers } \\
\hline Self-esteem & $.50^{\star \star \star}$ & $.44^{\star \star \star}$ & $.30^{\star \star}$ \\
\hline Behavioural adaptability & $.47^{\star \star \star}$ & $.42^{* \star *}$ & $.34^{* * *}$ \\
\hline Emotional literacy & $\mathrm{n} / \mathrm{s}$ & $.29^{\star \star}$ & $\mathrm{n} / \mathrm{s}$ \\
\hline Social connectivity & $.28^{\star *}$ & $.26^{\star \star}$ & $n / s$ \\
\hline
\end{tabular}

Note. $n=111 .{ }^{* *} p \leq .001 .{ }^{* *} p \leq .01 .{ }^{*} p \leq .05$. Correlation values $\leq .29$ are practically significant (small effect). Correlation value $\geq .30$ $\leq .49$ are practically significant (medium effect). Correlation values $\geq .50$ are practically significant (large effect). n/s: non-significant.

Table 3

Results of Stepwise Regression Analysis of Psychological Career Resources on work engagement

\begin{tabular}{|c|c|c|c|c|c|c|c|c|c|}
\hline & \multicolumn{3}{|c|}{ Vigour } & \multicolumn{3}{|c|}{ Dedication } & \multicolumn{3}{|c|}{ Absorption } \\
\hline & $\beta$ & $R^{2}$ & $\Delta R^{2}$ & $\beta$ & $R^{2}$ & $\Delta R^{2}$ & $\beta$ & $R^{2}$ & $\Delta R^{2}$ \\
\hline \multicolumn{10}{|l|}{ Model 1} \\
\hline Self-esteem & $.54^{\star \star \star}$ & $.25^{\star \star \star}$ & & & & & & & \\
\hline Behavioural adaptability & $.54^{\star \star}$ & $.28^{*}$ & $.03^{\star}$ & & & & & & \\
\hline Career purpose & $-.34^{\star \star}$ & $.34^{*}$ & $.06^{\star *}$ & & & & & & \\
\hline Career venturing & -.19 & .35 & .01 & & & & & & \\
\hline Authority/influence & .17 & .38 & .03 & & & & & & \\
\hline$F: 12.60^{* * *}$ & & & & & & & & & \\
\hline \multicolumn{10}{|l|}{ Model 2} \\
\hline Self-esteem & & & & $.57^{\star \star \star}$ & $.20^{\star * *}$ & & & & \\
\hline Behavioural adaptability & & & & $.69^{\star * *}$ & $.23^{*}$ & $.03^{*}$ & & & \\
\hline Career venturing & & & & $-.28^{\star *}$ & $.27^{\star \star}$ & $.04^{\star *}$ & & & \\
\hline Self/other skills & & & & $-.41^{*}$ & $.30^{\star}$ & $.03^{*}$ & & & \\
\hline Stability/expertise & & & & -.31 & .31 & .03 & & & \\
\hline Authority/influence & & & & .20 & .33 & .02 & & & \\
\hline \multicolumn{10}{|l|}{$\mathrm{F}: 8.70^{\star \star \star}$} \\
\hline \multicolumn{10}{|l|}{ Model 3} \\
\hline Behavioural adaptability & & & & & & & $.54^{\star \star \star}$ & $.12^{\star \star \star}$ & - \\
\hline$F: 14.97^{* * *}$ & & & & & & & & & \\
\hline
\end{tabular}

Note. $n=111 .{ }^{* *} p \leq .001 .{ }^{* *} p \leq .01 .{ }^{*} p \leq .05$. All statistics are from the final step. $\beta=$ standardised regression coefficient. $R^{2} \leq 0.12$ (small practical effect size). $R^{2} \geq .13 \leq 0.25$ (medium practical effect size). $R^{2} \geq .26$ (large practical effect size). 
cation. Model 3 shows that only behavioural adaptability contributed positively to explaining the variance in absorption $(\beta=.54 ; p \leq .0001)$. Model 3 explains only $12 \%\left(R^{2}=.12 ; p\right.$ $\leq .001$; small practical effect) of the variance in absorption.

\section{Discussion}

Overall, the results indicated that the participants' self-esteem and behavioural adaptability significantly and positively contributed in predicting their feelings of vigour and dedication, whilst behavioural adaptability also significantly and positively predicted the participants' absorption in their work. The results also suggest that behavioural adaptability and self-esteem firstly contributed to explaining the variance in participants' energy levels, mental resilience and psychological availability to engage in work. Psychological resources predicted a higher sense of significance, inspiration and pride and seeking challenges. Behavioural adaptability specifically appeared to have contributed to explaining a heightened sense of work meaningfulness. These findings are consistent with the conservation of resources theory (Hobfoll, 2001, 2002) which postulates that gains in resources enrich other resources and lead to positive psychological development, personal resilience and growth.

The results suggest that the intrinsic motivational behavioural orientations underpinning the notion of behavioura adaptability acted as important personal resources in activating and enhancing the work engagement of the participants. Xanthopoulou et al. (2007) posit that positive self-evaluations support individuals in successfully coping with job demands, achieving work goals, and pursuing pathways for personal growth and development. Coetzee (2013) also posits that career harmonisers such as behavioural adaptability relate to individuals' self-perceived success in important areas such as self-esteem and positive relations with others, autonomy, personal growth, purpose, environmental mastery, and optimism.

A strong sense of purpose was associated with significantly lower levels of vigour. Career purpose was also shown as the dominant career driver and, along with the stability/expertise career preference and self/other skills, one of the strongest overall psychological career resources for the sample of participants. The participants scored the lowest on the vigour variable. It therefore appears from the results that although the group of consultants perceived their service-oriented work as meaningful and contributing to the broader society, the nature of their work negatively influenced their levels of emotional energy, cognitive liveliness and resilience. The results from a study by Coetzee and Schreuder (2009) suggest that service-oriented staff with a strong sense of career purpose tend to place stronger emphasis on the psychological fulfillment the work offers, their self-management and relationship skills and being able to form supportive connections with others, than on the task itself. Participants indicated a preference for the stability/expertise career which also explains the low need for career venturing. However, having a need for career stability and developing one's expertise is positively linked to a need for clear career paths and goals (Coetzee, 2008). Clarity about one's career goals stimulates health-promoting behaviours that lead to an increase of one's physical and emotional wellbeing (vigour) as well as an optimistic attitude towards oneself and one's life in general (Coetzee \& Esterhuizen, 2010).

Participants' self-management and interpersonal skills and their career venturing negatively predicted their dedication. Ca- reer venturing refers to individuals' willingness to move easily between career opportunities and take career risks (Coetzee, 2008,2013 ) which explains why dedication levels are likely to decrease when career venturing increases. The participants' apparent high level of self/other skills seems appropriate for the service-oriented occupational environment. Dedication relates to behaviours that result in work-related task investment and persistence (Konstam \& Lehmann, 2011). A possible explanation for the lower levels of dedication and the higher levels of self/other skills could be that, as individuals' ability to understand their own motives and emotions as well as those of others increases, this may increase their ability to build supportive networks, creating more career opportunities and increasing the confidence to venture into new career avenues.

\section{Limitations and Recommendations}

The present study was limited to a non-probability sample of predominantly early career stage white female employees in a South African payroll and human resource software and technology solutions services company. The findings can therefore not be generalised to other occupational, gender and age contexts. Furthermore, given the cross-sectional nature of the research design, this study can yield no statements about causation. Associations between the variables have therefore been interpreted rather than established. Longitudinal studies should be employed to establish the causal relationships amongst the variables. Further studies are needed with broader samples across various occupational, age and gender groups, and economic sectors to replicate and extend the findings.

\section{Conclusion}

The relationship between employees' psychological career resources and their work engagement are important factors to consider in their career development. The extent to which employees develop their self-esteem and behavioural adaptability will determine the level to which they feel energised, dedicated and absorbed in their jobs, which in turn will influence their involvement and commitment to their jobs in the organisation.

\section{References}

Alessandri, G., Caprara, G. V., \& Tisak, J. (2012a). Further explorations on the unique contribution of positive orientation to optimal functioning. European Psychologist, 17, 44-54.

Alessandri, G., Vecchione, M., Tisak, J., Deiana, G., Caria, \& Caprara, G. V. (2012b). The utility of positive orientation in predicting job performance and organizational citizenship behaviors. Applied Psychology - An International Review, 61(4), 669-698.

Bakker, A. B., Schaufeli, W. B., Leiter, M. P., \& Taris, T. W. (2008). Work engagement: An emerging concept in occupational health psychology. Work \& Stress, 22, 187-200.

Bezuidenhout, M. (2011). The development and evaluation of a measure of graduate employability in the context of the new world of work (Unpublished master's dissertation). University of Pretoria, Pretoria, South Africa.

Coetzee, M. (2008). Psychological career resources of working adults: A South African survey. South African Journal of Industrial Psychology, 34(2), 10-20.

Coetzee, M. (in press). A psychological career resources framework for contemporary career development. In $\mathrm{M}$. Coetzee (Ed.), Psychosocial career meta-capacities: Dy- 
namics of contemporary career development. Dordrecht, Netherlands: Springer.

Coetzee, M., \& Bergh, Z. (2009). Psychological career resources and subjective work experiences of working adults: An exploratory study. Southern African Business Review, 13(2), 1-25.

Coetzee, M. \& Esterhuizen, K. (2010). Psychological career resources as predictors of African graduates' coping resources: An exploratory study. South African Journal of Industrial Psychology, 36(1), Art. \#868, 10 pages. doi: 10.4102/sajip. v36i1.868

Coetzee, M., \& Schreuder, A. M. G. (2009). Psychological career resources as predictors of working adults' career anchors: An exploratory study. South African Journal of Industrial Psychology, 35(1), Article \#833, 13 pages. doi:10.4102/sajip.v35i1.833

Coetzee, M., \& Schreuder, A. M. G. (2012). Subjective work experiences, career orientations, and psychological career resources of working adults. South African Journal of Higher Education, 26(2), 813-828.

Coetzer, C. F., \& Rothmann, S. (2007). Job demands, job resources and work engagement of employees in a manufacturing organization. Southern African Business Review, 11(1), 17-32.

Converse, P. D., Pathak, J., DePaul-Haddock, A. M., Gotlib, T., \& Merbedone, M. (2012). Controlling your environment and yourself: Implications for career success. Journal of Vocational Behavior, 80, 148-159.

Deci, E. L. \& Ryan, R. M. (1985). Intrinsic motivation and self-determination in human behavior. New York, NY: Plenum.

Deci, E. L., \& Ryan, R. M. (2000). The "what" and "why" of goal pursuits: Human needs and the internal motivation of behavior. Psychological Inquiry, 11, 227-268.

Demerouti, E., Bakker, A. B., Nachreiner, F., \& Schaufeli, W. B. (2001). The job demands-resources model of burnout. Journal of Applied Psychology, 86, 499-512.

Emmerling, R., \& Cherniss, C. (2003). Emotional intelligence and the career choice process. Journal of Career Assessment, 11(2), 153-167.

Ferreira, N. (2010). The relationship between psychological career resources and organisational commitment (Unpublished master's dissertation). University of Pretoria, Pretoria.

Ferreira, N. (2012). Constructing a psychological profile for staff retention (Unpublished doctoral thesis). University of South Africa, Pretoria, South Africa.

Ferreira, N., \& Coetzee, M. (2010). Psychological career resources and organisational commitment: Exploring socio-demographic differences. South African Journal of Labour Relations, 34(2), 25-41.

Ferreira, N., Basson, J., \& Coetzee, M. (2010). Psychological career resources in relation to commitment: An exploratory study. South African Journal of Human Resource Management, 8(1), 1-10.

Field, A. (2009). Discovering statistics using SPSS (3rd ed.). Thousand Oaks, CA: Sage.

Hobfoll, S. E. (2001). The influence of culture, community, and the nested-self in the stress process: Advancing conservation of resources theory. Applied Psychology - An International Review, 50, 337-370.
Hobfoll, S. E. (2002). Social and psychological resources and adaptation. Review of General Psychology, 6(4), 307-324.

Hobfoll, S. E., Johnson, R. J., Ennis, N., \& Jackson, A. P. (2003). Resource loss, resource gain, and emotional outcomes among inner city women. Journal of Personality and Social Psychology, 84, 632-643.

Kahn, W. A. (1990). Psychological conditions of personal engagement and disengagement at work. The Academy of Management Journal, 33(4), 692-724.

Konstam, V., \& Lehman, I. S. (2011). Emerging adults at work and play: Leisure, work engagement, and career indecision. Journal of Career Assessment, 19(2), 151-164.

Macey, W. H., \& Schneider, B. (2008). The meaning of employee engagement. Industrial and Organizational Psychology, 1(1), 3-30.

May, D. R., Gibson, R. L., \& Harter, L. M. (2004). The psychological conditions of meaningfulness, safety and availability of the human spirit at work. Journal of Occupational and Organizational Psychology, 77(1), 1-37.

Mendes, F., \& Stander, M. (2011). Positive organisation: The role of leader behaviour in work engagement and retention. South African Journal of Industrial Psychology, 37(1), 29-41.

Mirheidary, A., Siadat, S. A., Hoveida, R., \& Abedi, M.R. (2012). Relationship between organizational learning and work engagement at Isfahan steel mill company. Interdisciplinary Journal of Contemporary Research in Business, 4(3), 314-319.

Potgieter, I. L. (2012). The development of a career meta-competency model for sustained employability (Unpublished doctoral thesis). University of South Africa, Pretoria.

Ryan, R. M., \& Deci, E. L. (2000). Self-determination theory and the facilitation of intrinsic motivation, social development, and wellbeing. American Psychologist, 55, 68-78.

Salmela-Aro, K., Mutanen, P., \& Vuori, J. (2012). Promoting career preparedness and intrinsic work-goal motivation: RCT intervention. Journal of Vocational Behavior, 80, 67-75.

Savickas, M. L. (2011). New questions for vocational psychology: premises, paradigms, and practices. Journal of Career Assessment, 19(3), 251-258.

Savickas, M. L., \& Porfeli, E. J. (2012). Career Adapt-Abilities Scale: Construction, reliability, and measurement equivalence across 13 countries. Journal of Vocational Behavior, 80, 661-673.

Schaufeli, W. B., Bakker, A. B., \& Salanova, M. (2006). The measurement of work engagement with a short questionnaire: A cross-national study. Educational and Psychological Measurement, 66(4), 701-716.

Schaufeli, W. B., Bakker, A. B., \& Van Rhenen, W. (2009). How changes in job demands and resources predict burnout, work engagement, and sickness absenteeism. Journal of Organizational Behavior, 30, 893-917.

Sheldon, K. M. (2002). The self-concordance model of healthy goal-strving: When personal goals correctly present the person. In E. L. Deci \& R. M. Ryan (Eds.), Handbook of self-determination research (pp. 65-86). Rochester, NY: University of Rochester Press.

Sternberg, R. J. (2003). Implications of the theory of successful intelligence for career choice and development. Journal of Career Assessment, 11(2), 136-152. 
Super, D. E. (1990). A life-span, life-space approach to career development. In D. Brown \& L. Brooks (Eds.), Career choice and development (2nd ed., pp. 197-261). San Francisco, CA: Jossey-Bass.

Super, D. E. (1995). Values: Their nature, assessment and practical use. In D. E. Super, B. Sverko, \& C. Super (Eds.), Life roles, values, and careers: International findings of the work importance study (pp. 55-61). San Francisco, CA: Jossey-Bass.

Symington, N. (2012). Investigating gradute employability and psycholgical career resources (Unpublished master's dissertation). University of Pretoria, Pretoria, South Africa.

Tladinyane R. T. (2013). Psychological career resources, work engagement and organisational commitment: A psychological profile for staff retention (Unpublished doctoral thesis). University of South Africa, Pretoria, South Africa.

Tremblay, M. A., \& Messervey, D. (2011). The job demands-resources model: Further evidence for the buffering effect of personal resources. South African Journal of Industrial Psychology, 37(2), 10-19.

Vecina, M. L., Chacón, F., Sueiro, M., \& Barrón, A. (2012). Volunteer engagement: Does engagement predict the degree of satisfaction among new volunteers and the commitment of those who have been active longer? Applied Psychology - An International Review, 61(1), 130-148.

Verbruggen, M. (2012). Psychological mobility and career success in the 'new' career climate. Journal of Vocational Behavior, 81, 289-297.

Weigl, M., Hornung, S., Parker, S., Petru, R., Glaser, J., \& Angerer, P. (2010). Work engagement accumulation of task, social, personal resources: A three-wave structural equation model. Journal of Vocational Behavior, 77, 140-153.

Xanthopoulou, D., Bakker, A. B., Demerouti, E., \& Schaufeli, W. B. (2007). The role of personal resources in the job demands-resources model. International Journal of Stress Management, 14, 121-141. 